\title{
Health risk attributed to poor microbial quality of drinking water from rural area of Peshawar, Pakistan
}

Shehryar Ahmad ${ }^{1,2 *}$, Fazal Shan ${ }^{1}$, Syed Babar Ali ${ }^{3}$, Nasir $\mathrm{Ali}^{2}$, Muhammad Kamil Khan ${ }^{4}$ and Waqas Ahmad ${ }^{1}$

1. National Institute of Health and management sciences Peshawar, Pakistan

2. Mardan College of Medical Technology-Bacha Khan Medical College Mardan, Pakistan

3. Mardan College of Nursing Mardan-Bacha Khan Medical College Mardan, Pakistan

4. Student Sarhad University of Science and Information Technology, Pakistan

*Corresponding author's email: shery9444@gmail.com

Citation

Shehryar Ahmad, Fazal Shan, Syed Babar Ali, Nasir Ali, Muhammad Kamil Khan and Waqas Ahmad. Health risk attributed to poor microbial quality of drinking water from rural area of Peshawar, Pakistan. Pure and Applied Biology. Vol. 10, Issue 4, pp1364-1368. http://dx.doi.org/10.19045/bspab.2021.100141

\begin{tabular}{llll}
\hline \hline Received: 14/01/2021 & Revised: 26/03/2021 & Accepted: 05/04/2021 & Online First: 22/04/2021 \\
\hline \hline
\end{tabular}

\section{Abstract}

Waterborne diseases caused by potentially fatal microorganism is a major public health concern and impart severe health consequences in form of morbidity while severe cases lead to mortality. The current study aims to determine the microbiological quality of drinking water from the rural area of Peshawar Pakistan. A total of 600 samples were collected from budhni, chamkani and muslim town in 2018. This cross-sectional was approved by the National Institute of health and management sciences Peshawar. A sterile water container was used for a sample collection from both tap water and hand pump by adapting standard microbiological practices. Out of 600 samples, $275(45.7 \%)$ samples were positive for potential microorganisms including Salmonella (15\%), Shagella (32.8\%), and E. coli (11.7\%) respectively. A significant number of growth of Shigella, Salmonella and E. coli from a source of hand pump were observed in comparison to tap water. The presence of potential fatal microorganisms indicates poor quality of drinking water in the study setting which impart severe health consequences. Public health measures are required for reducing the prevalence of waterborne diseases in such areas.

Keywords: Contamination; Drinking water; Public health; Water borne diseases

Introduction

Water is a basic need for all living things and important for life survival. Sufficient, safe, and accessible supply must be needed to all and have detrimental benefits to health [1]. Safe drinking water is currently a major public health concern as human morbidity is closely tied to the quality of water [2]. Water quality gets poor due to an increase in population, industrial development, and unhygienic conditions in all parts of the world [3]. In developing countries, water pollution is one of the alarming issues, especially caused by animal waste, industrial, household effluent, and heavy metals [4].

In the USA it has been predicted that 560,000 per year people are suffering from waterborne diseases causing approximately 12000 deaths per year. According to WHO in their report on World in danger of missing 
sanitation target; reported that more than 1.1 billion peoples currently lack access to safe drinking water in both rural and urban areas and about 2.6 billion lacks access to basic sanitation [5]. Another report by (WHO/UNICEF 2019) reported that about 4.2 billion people lack basic sanitation services and 297,000 children less than five years of age die because of poor hygiene, unsafe drinking water, and poor sanitation [6] whereas 2 billion people live in a high water stress area. Besides many efforts, a safe water supply is still a challenging task for stakeholders. Unsafe water is one of the reflective reasons behind illness especially intestinal disease i.e. diarrhea and dysentery. A variety of pathogenic enteric bacteria such as Enterotoxigenic Escherichia coli, Salmonella spp, and Shigella sp contribute to such illness [7]. Many studies reported a higher prevalence of water-borne pathogens in Pakistan previously. A study conducted in Lahore reported a $37.2 \%$ prevalence of water contamination by pathogenic bacteria [8].

An extensive study conducted previously in all provinces of Khyber-Pakhtunkhwa Pakistan demonstrated the high prevalence of bacterial contamination in urban areas [9] however there is scarce of literature on the microbial quality of drinking water in many rural areas of Peshawar Pakistan. Keeping in view the context of deleterious effects of water-borne pathogens on human health, the current study was designed to determine the bacteriological quality of drinking water contamination with pathogenic bacteria of rural areas of Peshawar city.

\section{Material and Methods}

\section{Sampling site and collection}

About 600 samples were collected from the rural area of Peshawar i.e. budhni, Chamkani, and shaheen Muslim town. All the mention places were away from Peshawar on the East with a distance of $10 \mathrm{Km}$. About half of the samples were collected from budhni, Chamkani having six thousand homes while rest were from Muslim town having three thousand homes. The sources of drinking water supply in these areas were probably closed systems (bore wells, hand pumps, and taps).

\section{Study design and technique}

This study was cross-sectional and a nonprobability convenient sampling technique was used for sample collection. This study was approved by the National Institute of Health and management science Peshawar. Water samples for bacteriological analysis were collected aseptically in Sterile 125 or $150 \mathrm{~mL}$ plastic bottle. All samples were analyzed within 6 hours of its collection followed by bacterial analysis.

\section{Sample processing}

Spread plate techniques were used after obtaining inoculum from each sample. The glassware and other tubes were sterilized in an autoclave for $15 \mathrm{~min}$ at $121^{\circ} \mathrm{C}$. All samples were cultured on MacConkey and S.S agar. Both MacConkey and S.S agar plates are prepared according to the manufacturer's instructions. After inoculation, the media were incubated for 24 hours at $37^{\circ} \mathrm{C}$ and processed further for identification of bacteria.

\section{Bacterial identification}

Samples were processed for colony morphology and gram staining. Biochemical properties were also tested using biochemical tests i.e. Triple Sugar Iron, Indole, citrate, and urease test.

\section{Data analyses}

Data were analyzed using SPSS version 19 using the descriptive statistical tool. Data were presented in the form of tables.

\section{Results}

About 600 samples of water from hand pumps and tape water all around the areas of Budni, chamkani, and Muslim town were screened for different waterborne bacteria like Shigella, Salmonella, and E. coli. out of 600 samples, 145 samples were observed for the growth of Shigella (24.1\%), 105 samples 
for the growth of Salmonella (17.5\%) while 25 samples have growth of E. coli $(4.1 \%)$ respectively. The (Table 1) shows the growth status of the analyzed sample along with the organism type.

The (Table 2) shows the high number of growth for Shigella, Salmonella and E. coli from the source of hand pump $160(26.67 \%)$ in comparison to tap water $115(19.12 \%)$ respectively.

The percentage of Shigella was $53.4 \%$ from the sample collected from hand pumps and $22.1 \%$ in tape water while the prevalence of Salmonella was found to be $40 \%$ in hand pump water and $10.2 \%$ in tape water. E. coli was least prevalent with the percentage of $0.8 \%$ in hand pump water and $4.9 \%$ in tape water isolated in budhni and chamkani as shown in (Table 3 ).

The prevalence of Salmonella was $42.1 \%$ in hand pump while $4.8 \%$ in tape water followed by Shigella having the percentage of $22.1 \%$ in hand pump and $10.7 \%$ in tape water. The percentage of E. coli was $1.1 \%$ in hand pump and $6.8 \%$ of tape water isolated in shaheen Muslim town as shown in (Table 4).

Table 1. Prevalence of shigella, Salmonella and $E$. coli in water samples

\begin{tabular}{|c|c|c|c|}
\hline S. No. & Organism & Positive samples & Percentage \\
\hline 1 & Shigella & 145 & $24.2 \%$ \\
\hline 2 & Salmonella & 105 & $17.5 \%$ \\
\hline 3 & E.coli & 25 & $4.1 \%$ \\
\hline 4 & No growth & 325 & $54.2 \%$ \\
\hline & Total & 600 & $100 \%$ \\
\hline
\end{tabular}

Table 2. Percentage wise distribution of positive sample from different sources

\begin{tabular}{|c|c|c|c|}
\hline S. No. & Source & Number grown bacteria & Percentage \\
\hline 1 & Hand Pump & 160 & $26.7 \%$ \\
\hline 2 & Tape & 115 & $19.1 \%$ \\
\hline 3 & No growth in both & 325 & $54.2 \%$ \\
\hline
\end{tabular}

Table 3. Prevalence of Shigella, Salmonella and E. coli from tape water and hand pumps in budhni and chamkani

\begin{tabular}{|c|c|c|c|c|c|}
\hline S. No. & Total samples & Source & \multirow{2}{*}{ Organism } & $\begin{array}{c}\text { Positive } \\
\text { sample }\end{array}$ & Percentage \\
\hline \multirow{2}{*}{1} & 115 & Hand pump & \multirow{2}{*}{ Shigella } & 61 & $53.4 \%$ \\
\cline { 2 - 3 } \cline { 5 - 6 } & 185 & Tap water & & 41 & $22.1 \%$ \\
\hline \multirow{2}{*}{2} & 115 & Hand pump & \multirow{2}{*}{ Salmonella } & 46 & $40.0 \%$ \\
\cline { 2 - 3 } \cline { 5 - 6 } & 185 & Tap water & \multirow{2}{*}{ E.coli } & 19 & $10.2 \%$ \\
\cline { 2 - 3 } \cline { 5 - 6 } & 115 & Hand pump & 9 & $0.8 \%$ \\
\hline
\end{tabular}


Table 4. Prevalence of Shigella, Salmonella and E. coli from tape water and hand pumps in Muslim town

\begin{tabular}{|c|c|c|c|c|c|}
\hline S. No. & Total samples & Source & Organism & $\begin{array}{c}\text { Positive } \\
\text { sample }\end{array}$ & Percentage \\
\hline \multirow{2}{*}{1} & 95 & Hand pump & \multirow{2}{*}{ Shigella } & 21 & $22.1 \%$ \\
\hline & 205 & Tap water & & 22 & $10.7 \%$ \\
\hline \multirow{2}{*}{2} & 95 & Hand pump & \multirow{2}{*}{ Salmonella } & 40 & $42.1 \%$ \\
\hline & 205 & Tap water & & 10 & $4.8 \%$ \\
\hline \multirow{2}{*}{3} & 95 & Hand pump & \multirow{2}{*}{ E.coli } & 1 & $1.1 \%$ \\
\hline & 205 & Tap water & & 14 & $6.8 \%$ \\
\hline
\end{tabular}

\section{Discussion}

Pathogenic microorganisms have been a major public health challenge. One of the major sources of human infections is due to drinking of contaminated water. Microbial quality of water is guided by the water quality guidelines [10] or standards of the Department of Water Affairs and Forestry (DWAF, 1996). In light of such guidelines for drinking water quality, the results of the present study indicated that the water source tested was of poor microbiological quality. Poor microbiological quality of water possesses deleterious health effects on single intake in comparison to chemical contaminants as it leads to potential health consequences like diarrhea [11]. Our study revealed the growth of Shigella with a frequency of $24.1 \%$, Salmonella with $17.5 \%$, and $E$. coli with $4.1 \%$ respectively. Sample sources from hand pumps have observed growth of $26.7 \%$ while in tape water accounts for $19.1 \%$. The study conducted previously reported the prevalence of $(40 \%)$ microbial contamination which is quite similar to our study [9].

Our study indicates $54.2 \%$ of water sample are satisfactory for drinking purpose. The rest of the samples were not satisfactory for drinking purposes having microbial contamination. A study previously conducted reports similar findings which indicate the poor quality status of drinking water. Another study conducted in Lahore, Pakistan by Shoaib et al. [12] reported the high prevalence of water-borne pathogen with the percentage of $37.2 \%$ as Lahore is also an industrialized and highly populated area which makes the condition favorable for the rapid spread of water-borne pathogens like Salmonella, Shigella, and E. coli [8]. A study conducted by shoaib et al. [12] reported contamination of $56.1 \%$ which is in line with our findings.

In our study percentage of Shigella was $32.8 \%$ in tape water while the prevalence of Salmonella was $15 \%$ followed by E. coli with a percentage of $11.7 \%$ from the samples collected in budhni, chamkani, and muslim town. A similar study conducted by Din M et al from Quetta Pakistan reported a high percentage of pathogenic bacteria. Out of their 125 samples, 110 samples were contaminated and the most prominent bacteria was $E$. coli with the percentage of 28.8 followed by salmonella having a percentage of $04 \%$ respectively [13].

\section{Conclusion}

The presence of potential bacteria in drinking water in the present study attracts public health action as water-borne diseases caused by potentially fatal bacteria have drastic effects on consumers. Three major bacteria i.e Salmonella, Shigella, and E.Coli were most prevalent in the study setting which might be the etiologic factor behind waterborne diseases such as diarrhea and dysentery.

\section{Authors' contributions}

Conceived and designed the experiments: Sh Ahmad \& Fa Shan, Performed the experiments: Fa Shan, Wa Ahmad \& MK 
Khan, Analyzed the data: Na Ali, SB Ali \& SH Ahmad, Contributed materials/ analysis/ tools: FA Shan \& MK Khan, Wrote the paper: SH Ahmad.

\section{References}

1. Water S \& Organization WH (2006). Guidelines for drinking-water quality [electronic resource]: incorporating first addendum. Vol 1, Recommendations.

2. Jayana BL, Prasai T, Singh A \& Yami KD (1970). Assessment of Drinking Water Quality of Madhyapur-Thimi and Study of Antibiotic Sensitivity against Bacterial Isolates. Nepal J of Sci and Technol 10: 167-172.

3. Yildirim NC, Yildirim N, Kaplan O \& Tayhan N (2010). Evaluation of chemical and microbiological contamination levels in drinking water samples collected from towns in Tunceli, Turkey. Inter J of Agric and Biol 12(6): 957-960.

4. Bryant SD (2004). Lead contaminated drinking waters in the public schools of Philadelphia. J of Toxicol: Clin Toxicol 42(3): 287-294.

5. WHO. World in danger of missing sanitation target; drinking-water target also at risk, new report shows.

6. Water United Nations.

7. Nyarko H, Arthur SA \& Birikorang E (2011). A study of antibiotic susceptibility pattern of bacteria isolates in sachet drinking water sold in the cape coast metropolis of Ghana.

8. Anwar MS, Lateef S \& Siddiqi GM (2010). Bacteriological quality of drinking water in Lahore. Biomedica 26(1): 66-69.

9. Daud MK, Nafees M, Ali S, Rizwan M, Bajwa RA, Shakoor MB et al. (2017). Drinking Water Quality Status and Contamination in Pakistan. Biol Med Res Inter 7908183.

10. DWAF (1996) South African Water Quality Guidelines: Domestic Use (second edition).

11. Nabeela F, Azizullah A, Bibi R, Uzma S, Murad W, Shakir S et al. (2014). Microbial contamination of drinking water in Pakistan-a review. Environ Sci and Poll Res Inter 21.

12. Shoaib M, Asad MJ, Aziz S, Usman M, Rehman A, Zafar MM et al. (2016). Prevalence of Pathogenic Microorganisms in Drinking Water of Rawalpindi and Islamabad 8(1): 14-21.

13. Din M, Ahmad Z, Aleem A, Pirkani GS, Mohammad A \& Ahmad N (2014). Pathogens from Drinking Water; Isolation and antibiogram of pathogenic organisms from drinking water in Quetta city. Prof Med J 21(4). 